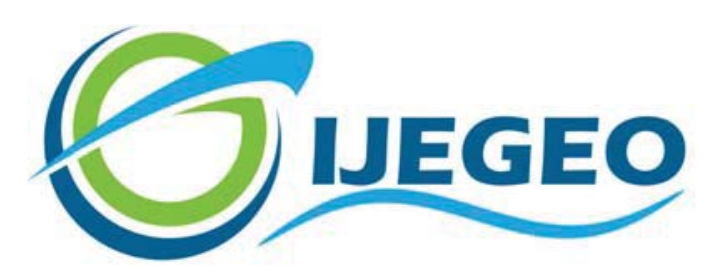

International Journal of Environment and Geoinformatics (IJEGEO) is an international, multidisciplinary, peer reviewed, open access journal.

\title{
Trace metal-induced ecological risk analysis of Sarıçay River sediments, Çanakkale, NW Turkey
}

\section{Taylan AKARSU, Serkan KÜKRER, Ahmet Evren ERGINAL}

\author{
Chief in Editor \\ Prof. Dr. Cem Gazioğlu
}

Co-Editors Prof. Dr. Dursun Zafer Şeker, Prof. Dr. Şinasi Kaya,

Prof. Dr. Ayşegül Tanık and Assist. Prof. Dr. Volkan Demir

Editorial Committee (June 2022)

Assoc. Prof. Dr. Abdullah Aksu (TR), Assoc. Prof. Dr. Uğur Algancı (TR), Assoc. Prof. Dr. Aslı Aslan (US), Prof. Dr. Levent Bat (TR), Prof. Dr. Paul Bates (UK), İrşad Bayırhan (TR), Prof. Dr. Bülent

Bayram (TR), Prof. Dr. Luis M. Botana (ES), Prof. Dr. Nuray Çağlar (TR), Prof. Dr. Sukanta Dash (IN), Dr. Soofia T. Elias (UK), Prof. Dr. A. Evren Erginal (TR), Assoc. Prof. Dr. Cüneyt Erenoğlu (TR), Dr. Dieter Fritsch (DE), Prof. Dr. Ç; Prof. Dr. Manik Kalubarme (IN), Dr. Hakan Kaya (TR), Assist. Prof. Dr. Serkan Kükrer (TR), Assoc. Prof. Dr. Maged Marghany (MY); Prof. Dr. Micheal Meadows (ZA), Prof. Dr. Nebiye Musaoğlu (TR), Prof. Dr. Masafumi Nakagawa (JP), Prof. Dr. Hasan Özdemir (TR), Prof. Dr. Chyssy Potsiou (GR), Prof. Dr. Erol Sarı (TR), Prof. Dr. Maria Paradiso (IT), Prof. Dr. Petros Patias (GR), Prof. Dr. Elif Sertel (TR), Prof. Dr. Nüket Sivri (TR), Prof. Dr. Füsun Balık Şanlı (TR), Dr. Duygu Ülker (TR), Prof. Dr. Seyfettin Tsaş (TR), Assoc. Prof. Dr. Ömer Suat Taşkın (TR), Assist. Prof. Dr. Tuba Ünsal (TR), Assist. Prof. Dr. Sibel Zeki (TR) 


\title{
Trace metal-induced ecological risk analysis of Sarıçay River sediments, Çanakkale, NW Turkey
}

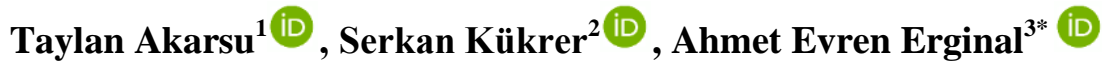 \\ ${ }^{1}$ Ataturk University, Kazim Karabekir Faculty of Education, Department of Geography Education, Erzurum, Turkey \\ ${ }^{2}$ Ardahan University, Faculty of Humanities and Letters, Department of Geography, Ardahan, Turkey \\ ${ }^{3}$ Çanakkale Onsekiz Mart University, Faculty of Education, Department of Geography Education, Çanakkale, Turkey \\ * Corresponding author: A.E. Erginal \\ Received 01.09.2021 \\ E-mail: aerginal@gmail.com \\ Accepted 03.10.2021 \\ How to cite: Akarsu et al., (2022). Trace metal-induced ecological risk analysis of Sarıçay River sediments, Çanakkale, NW Turkey, \\ International Journal of Environment and Geoinformatics (IJEGEO), 9(2):045-053, doi. 10.30897/ijegeo. 989882
}

\begin{abstract}
Metals have come to the fore among the pollutants monitored in aquatic ecosystems in recent years. Fresh waters especially constitute a "hot spot" due to their limited reserves. In order to analyze the sources of metal-induced pollution, ecological risk level and pollutants of the Sarıçay River passing through the city of Çanakkale, sediment samples were collected from 26 stations and element analyses were carried out in ICP-MS. Anthropogenic effects and the risks they cause were determined by calculating the enrichment factor, geoaccumulation index, and potential ecological risk from the obtained data. Anthropogenic enrichment was detected for $\mathrm{Cr}, \mathrm{Ni}, \mathrm{Pb}, \mathrm{Au}, \mathrm{Ag}$ and $\mathrm{Ba}, \mathrm{Bi}, \mathrm{Tl}, \mathrm{Na}, \mathrm{Zn}, \mathrm{Mg}, \mathrm{K}, \mathrm{As}, \mathrm{Sb}$, and $\mathrm{Mn}$ with the largest amount being $\mathrm{Cd}$. The level of enrichment varies from moderate to very high. According to the results of risk analysis, a moderate risk for $\mathrm{Cd}$ was determined and a very high risk for $\mathrm{Ni}$ and $\mathrm{Pb}$. Agricultural activities, atmospheric deposition and mineral deposits in the basin were identified as the major sources from the multivariate statistical analysis performed to determine the main sources of metal inflows.
\end{abstract}

Keywords: Trace metal, Pollution, Ecological risk, Sarıçay Stream, Çanakkale, Turkey.

\section{Introduction}

Coastal plains, in particular river deltas, have been amongst the most preferred areas for establishing cities since early times. Due to the increasing need for water in cities arising from population growth along with the development of agriculture and industry, water and sediment pollution in nearby rivers now poses an environmental threat (Esetlili et al., 2018; Algan et al., 2002; Tchounwou et al. 2012). The serious increase of contaminants is substantially caused by the input of trace metals due to use of fertilizers ( $, \mathrm{P}, \mathrm{K}, \mathrm{Cu}, \mathrm{Fe}, \mathrm{As}$ and $\mathrm{Cd}$ ), sewage (As, $\mathrm{Cr}, \mathrm{Cu}, \mathrm{Mn}$ and $\mathrm{Ni}$ ), and industrial waste $(\mathrm{Cd}, \mathrm{Ni}, \mathrm{Pb}, \mathrm{Se}, \mathrm{As}$ and $\mathrm{Hg})$, leading to physicochemical and biological changes in various elements of sensitive ecosystems, such as plants (Hawkes, 1997; Nagajyoti et al., 2010), soils (Wei et al., 2016), people (Duruibe et al., 2007), and microorganisms living in water (Förstner and Prosi, 1979). The local inhabitants are especially exposed to trace metal pollution as these toxic matters retained in soft tissues cannot be removed by the body (Jarup, 2003; $\mathrm{Xu}$ et al., 2018). For example, at high levels, arsenic has a carcinogenic effect (Tchounwou et al., 2003), cadmium, lead and mercury can cause kidney disease (Xu et al., 2018) and chromium can damage the cardiovascular system.

In recent years, there has been considerable interest in the impacts of human-induced trace metal pollution in the water and sediment quality of the largest rivers in the world (Benet, 2019; Zhou et al., 2020) such as the Amazon (Telxeira et al., 2018), Brahmaputra (Saikia et al., 2016), Yamuna (Pandey et al., 2011), Ganga (Paul, 2017), Lerna (Mendoza et al., 2018), Niger (Izah et al., 2017), Nile (Lasheen and Ammar, 2009; El Bouraie et al., 2010; Satar et al., 2017), Danube (Rusina et al., 2019; Belis et al., 2019; Abonyi et al., 2019) and Po (Farkas et al., 2007). In Turkey, densely populated cities have also been established along the $8333 \mathrm{~km}$-long coastline, especially alongside rivers and on delta plains where overpopulation leads to the same environmental risks (Gazioğlu, 2018).

Among the most polluted urban areas, those in the Marmara Region where industrialization is at its highest level are under risk of ecological degradation. On the southern coast of Istanbul, the Strait of Istanbul (Bosphorus) and river mouths in its vicinity are seriously affected by ecological risk due to metal enrichment in sediments (Sur et al., 2004; Gazioğlu et al., 2002; Ünlü and Alpar, 2015; Haciyakupoglu et al., 2015; Salr and Gazioğlu, 2021). Domestic wastes as well as industrial inputs lead to heavy pollution in Izmit Bay to the east of the Marmara Sea (Pekey et al., 2004). On the Black Sea coast of Turkey where cities are aligned alongside the coast due to the mountains behind, trace metal pollution in stream waters and sediments as well as fish tissues are caused mostly by anthropogenic sources and mining activities (Gedik and Boran, 2013; Ozseker et al., 2013, 2014, 2016; Polat et al., 2015; Engin et al., 2016; Ustaoglu and Tepe, 2019). The industrial, agricultural 
and domestic waste discharges into Büyükmenderes and Gediz rivers flowing into the Aegean Sea to the west result in a substantial level of pollution (Akcay et al., 2003; Esen et al., 2010; Akinci et al., 2013). Even in the southeastern Anatolia region of Turkey where industry is not so developed, pollution occurs at significant levels in rivers, as in the Tigris river (Gümgüm et al., 1994; Varol, 2011).

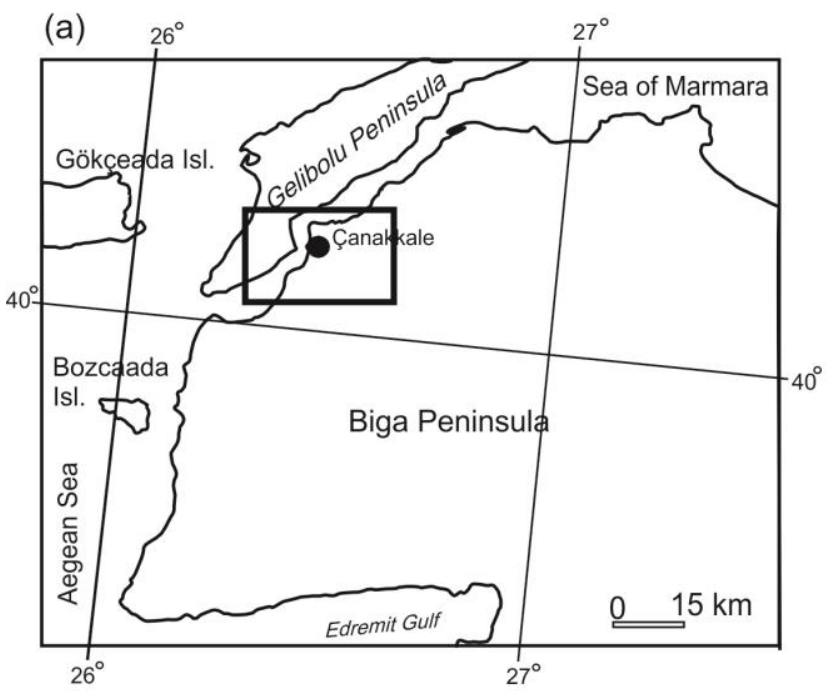

Fig.1. Location map of study area.

\section{Material and Methods Study area}

Saricay Stream is one of the most important streams in the Biga Peninsula, NW Turkey, which flows into the Çanakkale Straits, an international waterway connecting the Mediterranean with the Sea of Marmara (Fig. 1a,b). It has a drainage catchment area of $393.78 \mathrm{~km}^{2}$ (Öztürk and Erginal, 2001) and is exposed to serious flood potential, as understood from the 2010, 2012 and 2013 floods (Tiryaki, and Karaca, 2018). Unlike the other streams in Biga Peninsula, Sarıçay is the only stream where city developments exist. According to Çanakkale's climatic data from the Turkish State Meteorological Service between 1975 and 2018, the annual average temperature is $15.9^{\circ} \mathrm{C}$, annual total open surface evaporation is $1387.4 \mathrm{~mm}$, and the annual average precipitation is $613.73 \mathrm{~mm}$

The main inputs caused by agriculture, forestry, grazing, raw sewage, and industrial discharges may pose an ecological risk to the Sarıçay ecosystem. Along the Saricay Stream are many industrial plants such as food, leather, mining (lead, zinc and gold) and timber processing (Aksoy et al., 1997; Kocum and Dursun, 2007; Alkan, 2020). Additionally, on the sides of Saricay Stream, there are gas stations and an airport. All told, the increasing population, heavy traffic in Çanakkale city, busy Dardanelles shipping, fishing and boat
This study aims to analyze the ecological risk factors caused by metal pollution from sediments in the Sarıçay River, which flows through the city of Çanakkale into the Çanakkale Straits (Dardanelles), using different indices such as the enrichment factor, contamination factor, geoaccumulation index, pollution load index and potential ecological risk..

(b)

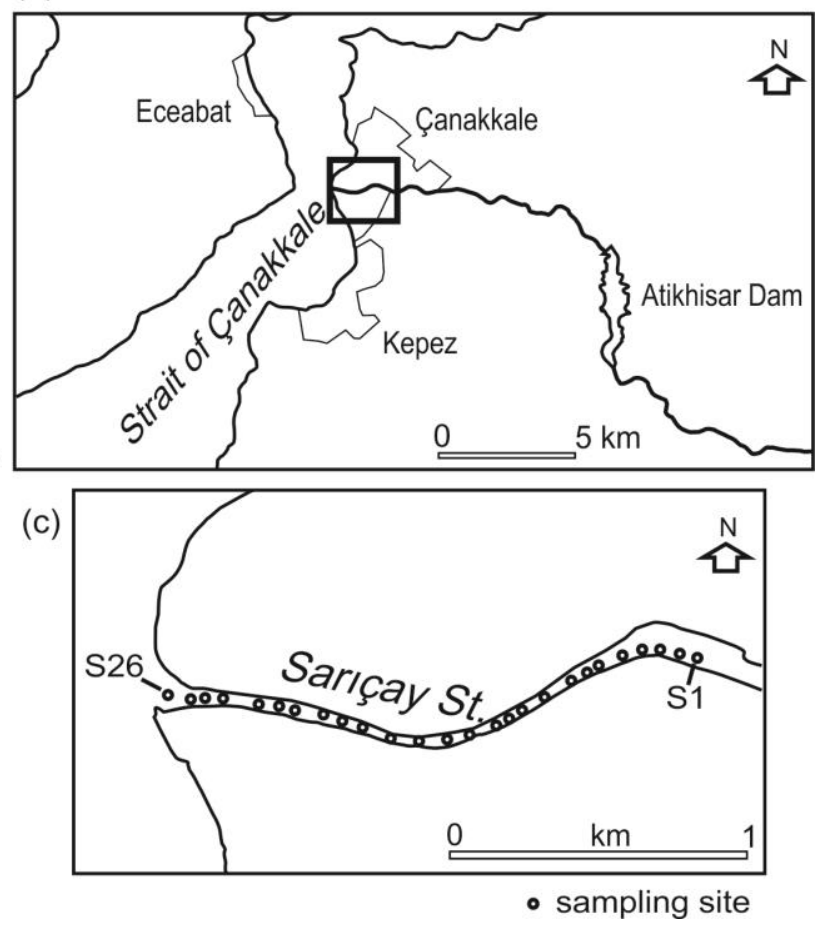

maintenance, and thermal power plants in the Biga Peninsula also contribute substantially to increased discharges.

\section{Sampling and analyses}

In this study, surface sediments were collected using a Van Veen grab sediment sampler from 26 different sites (stations) on the stream's channel alongside the urban development area (Fig. 1c). Additionally, 5 rock samples were collected to calculate the background values of the river basin. The trace metal concentrations $(\mathrm{Mn}, \mathrm{Ba}, \mathrm{Ag}$, $\mathrm{Zn}, \mathrm{Sr}, \mathrm{Hg}, \mathrm{Pb}, \mathrm{Cu}, \mathrm{V}, \mathrm{Cr}, \mathrm{Ni}, \mathrm{As}, \mathrm{Au}, \mathrm{Co}, \mathrm{Fe}, \mathrm{Ca}, \mathrm{Al}, \mathrm{U}$, $\mathrm{Sb}, \mathrm{Na}, \mathrm{Mg}, \mathrm{Cd}, \mathrm{Bi}, \mathrm{Tl}, \mathrm{K}, \mathrm{P}, \mathrm{Ti}$ ) in the samples were measured by using inductively coupled plasma mass spectrometry (ICP-MS) at the ACME (Bureau Veritas Commodities, Canada) laboratory. Based on multielement ICP-MS data, the enrichment factor (EF), contamination factor (CF), potential ecological risk (PER), geoaccumulation index (Igeo) and pollution load index (PLI) values were calculated. Principal Component Analysis was applied to the data set to determine the possible sources and transport processes of the elements. Spearman's correlation analysis was applied to determine the meaningful relationships between metals and cluster analysis was used to group the variables according to their similarities.

Enrichment factor (EF). Enrichment Factor (EF) analysis is used to measure whether the metal 
accumulation in the sediment comes from anthropogenic or natural sources. EF is obtained by dividing the current metal/reference element ratio by the successive metal/reference element ratio. For the reference element, conservative elements abundant in rocks such as $\mathrm{Fe}, \mathrm{Al}$, $\mathrm{Ca}, \mathrm{Ti}$ and $\mathrm{Mn}$ are generally used. In this study, Al was used as the reference element. According to Sutherland (2000), EF values are assessed as enrichment values, such as deficiency to minimal $(\mathrm{EF}<2)$, moderate $(\mathrm{EF}=2-$ 5), significant $(E F=5-20)$, very high $(E F=20-40)$ and extremely high $(\mathrm{EF}>40)$. In addition, in the literature we accept the limit of 1.5 for EF; in cases where the EF value is below 1.5, the enrichment of metals occurs by natural sources and processes. In cases where the EF value is greater than 1.5 , enrichment in metals is considered to occur as a result of anthropogenic effects (Bergamaschi et al., 2002).

Geo-accumulation index (Igeo). Geoaccumulation index (Igeo) analysis is another method used to determine anthropogenic effects on metal concentration in the sediment. Igeo is calculated using the formula below:

$$
\text { Igeo }=\log _{2} \frac{C_{m}}{1,5 * B_{m}}
$$

In the formula, $\mathrm{C}_{\mathrm{m}}$ is the measured concentration of the metal and $\mathrm{B}_{\mathrm{m}}$ is the background value of the metal. According to Müller (1969), Igeo values are considered as unpolluted (Igeo $<0$ ), unpolluted to moderately $(0$ $<$ Igeo $<1)$, moderately $(1<$ Igeo $<2)$, moderately to strongly $(2<$ Igeo $<3)$, strongly $(3<$ Igeo $<4)$, strong to extremely $(4<$ Igeo $<5)$ and extremely polluted (Igeo> 5).

Potential ecological risk index (PER). The Potential ecological risk index (PER) developed by Hakanson (1980) is used to predict the potentially toxic effects of metals deposited in the sediments of an ecosystem. The modified risk factor calculated separately for each metal (Eri) and the integrated risk factor (PER) include all metals to be evaluated (Hakanson, 1980; Zhang et al., 2017). The formula used for the PER of a single trace metal was:

$$
\operatorname{Eri}=\mathrm{E}_{\mathrm{f}}^{\mathrm{i}} \times \mathrm{T}_{\mathrm{f}}^{\mathrm{i}}
$$

where $E_{f}^{i}$ is the enrichment factor, and $T_{f}^{i}$ is the response coefficient for toxicity of a single trace metal. Response coefficients used for the metals were as follows: $\mathrm{Hg}=40$, $\mathrm{Cd}=30, \quad \mathrm{As}=10, \quad \mathrm{Cu}=\mathrm{Pb}=\mathrm{Ni}=5, \quad \mathrm{Cr}=2, \quad \mathrm{Zn}=1, \quad \mathrm{Mn}=.1$ $\mathrm{Co}=5, \mathrm{Tl}=10$ and $\mathrm{V}=2$ (Hakanson, 1980; RodriguezEspinosa et al., 2018; Li et al., 2018). The following classification was used to assess the risk factor (Hakanson, 1980): low potential ecological risk (Eri $<40$ ), moderate potential ecological risk $(40 \leq$ Eri $<80)$, considerable potential ecological risk $(80 \leq$ Eri $<160)$, high potential ecological risk $(160 \leq$ Eri $<320)$, and very high potential ecological risk (Eri $\geq 320)$.

Integrated PER values were calculated as follows:

$$
\operatorname{PER}=\sum \mathrm{E}_{\mathrm{f}}^{\mathrm{i}}
$$

PER values are considered as having low ecological risk (PER <150), moderate ecological risk $(150 \leq$ PER $<300)$, considerable ecological risk $(300 \leq$ PER $<600)$, or very high ecological risk $(\mathrm{PER} \geq 600)$.

\section{Results and Discussion Trace Metal Content}

Descriptive statistics of the metals are given in Table 1 . While the smallest values according to the element averages of the stations were measured at stations 18,14 and 16; the highest values were measured at stations 4, 2 and 5. The determined ranges of metals are as follows; Mn 331-1151 ppm, Ba 91.3-612.4 ppm, Ag 111-407 ppb, Zn 90.2-251.3 ppm, Sr 66.1-116.4 ppm, Hg 19-99 ppb, Pb 29.25-83.03 ppm, Cu 33.62-82.5 ppm, V 43-87 ppm, Cr 27.8-113.9 ppm, Ni 25.5-73.3 ppm, As 13.728.2 ppm, Au 5-68.6 ppb, Co 9.8-14.7 ppm, Fe 2.06$3.14 \%$, Ca 1.32-2.63\%, Al 1.35-2.74\%, U 1.3-2.2 ppm, Sb 0.66-1.42 ppm, Na 0.07-2.43\%, Mg 0.53-0.98\%, Cd 0.30-1 ppm, Bi 0.27-0.56 ppm, Tl 0.24-0.41 ppm, K $0.18-0.42 \%, \mathrm{P} 0.06-0.34 \%$ and $\mathrm{Ti}$ 0.01-0.04\%.

When metal concentrations of the surface sediment samples are compared with background values, it is seen that concentrations of the elements $\mathrm{Mn}, \mathrm{Ba}, \mathrm{Ag}, \mathrm{Zn}, \mathrm{Pb}$, $\mathrm{Cr}, \mathrm{Ni}, \mathrm{As}, \mathrm{Au}, \mathrm{Co}, \mathrm{Ca}, \mathrm{Al}, \mathrm{U}, \mathrm{Sb}, \mathrm{Mg}, \mathrm{Cd}, \mathrm{Bi}, \mathrm{K}$ and $\mathrm{P}$ are above the background values. On the other hand, the concentrations of elements $\mathrm{Sr}, \mathrm{Hg}, \mathrm{Cu}, \mathrm{V}, \mathrm{Fe}, \mathrm{Al}, \mathrm{Na}$ and $\mathrm{Ti}$ are below the background values. $\mathrm{Sr}$ concentrations were below the background value at stations 13 and 14, while $\mathrm{Hg}$ concentrations remained below the background value in all stations except $11,15,17,25$ and $26 . \mathrm{Cu}$ concentrations are below the background value in all sampled stations. Concentrations of $\mathrm{V}$ are below the background value in all stations except 2 and 6 . Fe concentrations were below the background value at station 21, while $\mathrm{Na}$ concentrations were determined below the background value in many stations, such as 1 , 2, 3, 4, 5, 7, 8, 9 and 13. Ti concentrations remained below the background value in all stations, as with $\mathrm{Cu}$. While element concentrations above background values are indicative of metal input from natural or human resources, values below background values are related to the easy removal of these elements from the medium.

\section{Ecological risks and possible sources}

Metals studied in Saricay River show a decreasing order in terms of the average enrichment factor as follows; $\mathrm{Cd}>\mathrm{Cr}>\mathrm{Ni}>\mathrm{Pb}>\mathrm{Au}>\mathrm{Ag}>\mathrm{Ba}>\mathrm{Bi}>\mathrm{Tl}>\mathrm{Na}>\mathrm{Zn}>\mathrm{Mg}>$ $\mathrm{K}>\mathrm{As}>\mathrm{Sb}>\mathrm{Mn}>\mathrm{P}>\mathrm{U}>\mathrm{Ca}>\mathrm{Co}>\mathrm{Al}>\mathrm{S}>\mathrm{Fe}>\mathrm{Hg}>\mathrm{V}>$ $\mathrm{Cu}>\mathrm{Ti}$ (Fig. 2). Considering the average enrichment values, we determined very high enrichment for $\mathrm{Cd}$, significant enrichment for $\mathrm{Cr}, \mathrm{Ni}, \mathrm{Pb}, \mathrm{Au}, \mathrm{Ag}$ and $\mathrm{Ba}$, and moderate enrichment for $\mathrm{Bi}, \mathrm{Tl}, \mathrm{Na}, \mathrm{Zn}, \mathrm{Mg}, \mathrm{K}$, As, $\mathrm{Sb}$, and $\mathrm{Mn}$. There is deficiency of minimal enrichment for $\mathrm{Co}, \mathrm{Al}, \mathrm{Sr}, \mathrm{Fe}, \mathrm{Hg}, \mathrm{V}, \mathrm{Cu}, \mathrm{P}, \mathrm{U}, \mathrm{Ca}$ and Ti metals. In terms of distribution by station, the stations with the highest enrichment are 20, 21, and 19, respectively, while the stations with the lowest enrichment are 10, 12, and 5 , respectively. 
Table 1. Descriptive statistics of 27 variables in Saricay.

\begin{tabular}{|c|c|c|c|c|c|c|c|c|c|c|c|c|c|c|}
\hline & $\mathbf{C u}$ & $\mathbf{P b}$ & $\mathbf{Z n}$ & Ag & $\mathrm{ppm}$ & Co & Mn & $\mathbf{F e}$ & As & $\begin{array}{c}\mathbf{U} \\
\mathrm{pp} \\
\mathrm{m}\end{array}$ & $\mathbf{A u}$ & $\mathrm{ppm}$ & $\begin{array}{c}\text { Cd } \\
\text { pp } \\
\text { m }\end{array}$ & \\
\hline & 55.4 & 56.1 & 186.6 & 225.4 & 38.2 & & & & 18.4 & 1.5 & 16.0 & 102.1 & 0.7 & \\
\hline \multirow[t]{2}{*}{ Mean } & 6 & 4 & 6 & 6 & 7 & 13.00 & 657.04 & 2.63 & 0 & 9 & 5 & 5 & 2 & \\
\hline & 33.6 & 29.2 & & 111.0 & 25.5 & & & & 13.7 & 1.3 & & & 0.3 & \\
\hline \multirow[t]{2}{*}{ Min } & 2 & 5 & 90.20 & 0 & 0 & 9.80 & 331.00 & 2.06 & 0 & 0 & 5.00 & 66.10 & 0 & \\
\hline & 82.5 & 83.0 & 251.3 & 407.0 & 73.3 & & 1151.0 & & 28.2 & 2.2 & 68.6 & 116.4 & 1.0 & \\
\hline \multirow[t]{2}{*}{ Max } & 0 & 3 & 0 & 0 & 0 & 14.70 & 0 & 3.14 & 0 & 0 & 0 & 0 & 0 & \\
\hline & 12.1 & 12.8 & & & 10.0 & & & & & 0.2 & 12.6 & & 0.1 & \\
\hline \multirow{5}{*}{$\begin{array}{l}\text { Std.deviation } \\
\text { Background } \\
\text { value }\end{array}$} & 2 & 0 & 38.07 & 65.42 & 8 & 1.22 & 229.78 & 0.30 & 3.67 & 3 & 1 & 11.65 & 7 & \\
\hline & 90.1 & & & & & & & & & 0.6 & & & 0.0 & \\
\hline & 1 & 4.28 & 36.58 & 24.40 & 2.98 & 6.14 & 221.80 & 2.10 & 6.02 & 8 & 1.42 & 73.12 & 2 & \\
\hline & Sb & $\mathbf{B i}$ & V & $\mathrm{Ca}$ & $\mathbf{P}$ & $\mathrm{Cr}$ & Mg & $\mathbf{B a}$ & $\mathbf{T i}$ & Al & $\mathbf{N a}$ & $\mathbf{K}$ & Tl & $\mathrm{Hg}$ \\
\hline & $\mathrm{ppm}$ & $\mathrm{ppm}$ & $\mathrm{ppm}$ & $\%$ & $\%$ & ppm & $\%$ & ppm & $\%$ & $\%$ & $\%$ & $\%$ & $\mathrm{~m}$ & $\mathrm{ppb}$ \\
\hline \multirow{3}{*}{ Mean } & & & & & & & & 366.3 & & 1.9 & & & 0.3 & 63.6 \\
\hline & 0.91 & 0.45 & 55.27 & 1.98 & 0.15 & 44.73 & 0.74 & 0 & 0.02 & 6 & 0.83 & 0.28 & 1 & 9 \\
\hline & & & & & & & & & & 1.3 & & & 0.2 & 19.0 \\
\hline \multirow[t]{2}{*}{ Min } & 0.66 & 0.27 & 43.00 & 1.32 & 0.06 & 27.80 & 0.53 & 91.30 & 0.01 & 5 & 0.07 & 0.18 & 4 & 0 \\
\hline & & & & & & 133.9 & & 612.4 & & 2.7 & & & 0.4 & 99.0 \\
\hline \multirow[t]{2}{*}{ Max } & 1.42 & 0.56 & 87.00 & 2.63 & 0.34 & 0 & 0.98 & 0 & 0.04 & 4 & 2.43 & 0.42 & 1 & 0 \\
\hline & & & & & & & & 150.9 & & 0.3 & & & 0.0 & 18.5 \\
\hline \multirow{3}{*}{$\begin{array}{l}\text { Std.deviation } \\
\text { Background } \\
\text { value }\end{array}$} & 0.18 & 0.06 & 11.03 & 0.32 & 0.06 & 26.66 & 0.13 & 9 & 0.01 & 8 & 0.86 & 0.08 & 4 & 9 \\
\hline & & & & & & & & & & 1.3 & & & 0.0 & 79.3 \\
\hline & 0.31 & 0.07 & 80.60 & 0.88 & 0.06 & 3.38 & 0.17 & 51.80 & 0.10 & 3 & 0.17 & 0.09 & 5 & 0 \\
\hline
\end{tabular}

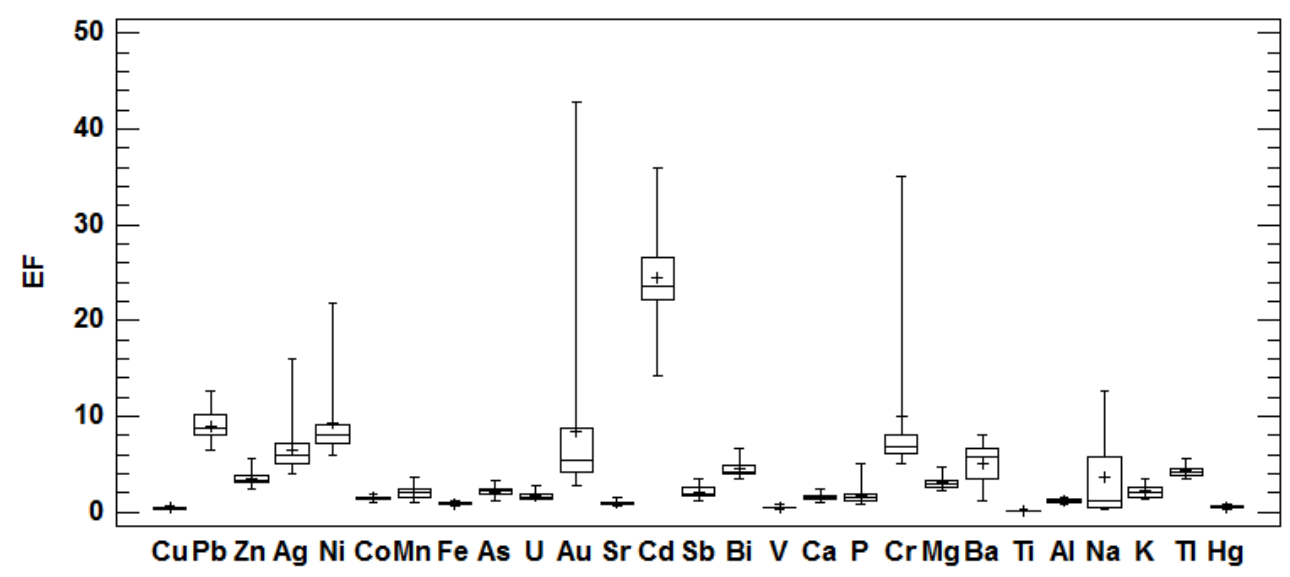

Fig.2. EF values of elements.

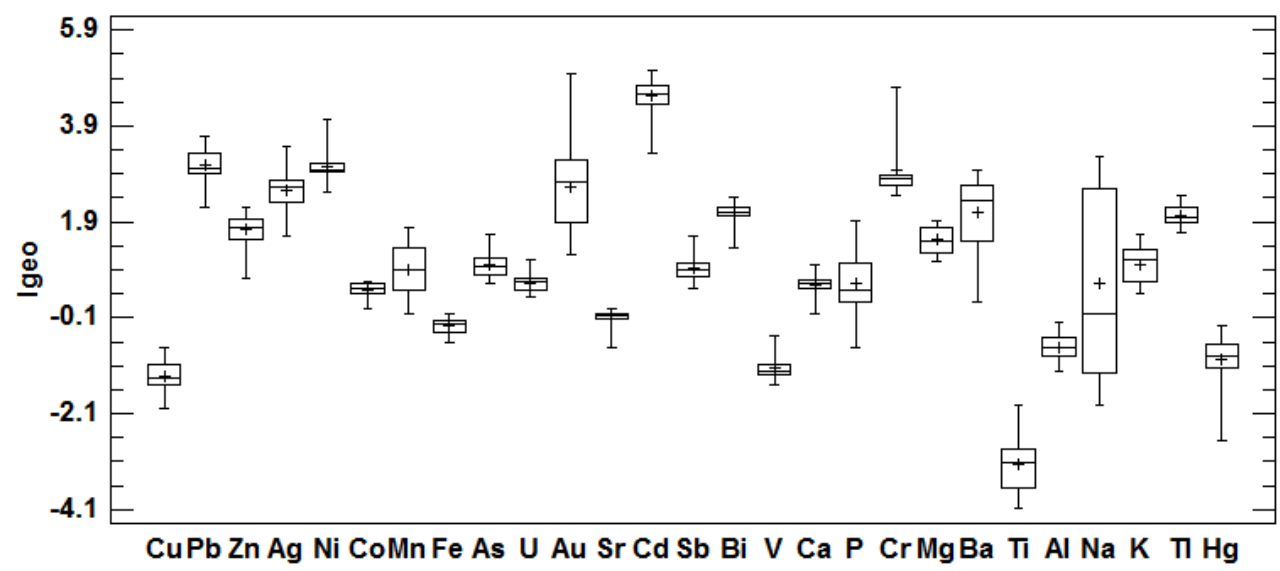

Fig.3. I geo values of elements. 
The average geoaccumulation values of heavy metals studied in Sarıçay River in descending order are as follows: $\mathrm{Cd}>\mathrm{Pb}>\mathrm{Ni}>\mathrm{Cr}>\mathrm{Au}>\mathrm{Ag}>\mathrm{Ba}>\mathrm{Bi}>\mathrm{Tl}>\mathrm{Zn}>$ $\mathrm{Mg}>\mathrm{K}>\mathrm{As}>\mathrm{Sb}>\mathrm{Mn}>\mathrm{U}>\mathrm{P}>\mathrm{Na}>\mathrm{Ca}>\mathrm{Co}>\mathrm{Sr}>\mathrm{Fe}>$ $\mathrm{Al}>\mathrm{Hg}>\mathrm{Cu}>\mathrm{Ti}$ (Fig. 3) Averages of the geoaccumulation values are strong to extremely contaminated for $\mathrm{Cd}$, strongly contaminated for $\mathrm{Pb}$ and $\mathrm{Ni}$, moderately to strongly contaminated for $\mathrm{Cr}, \mathrm{Au}, \mathrm{Ag}$, $\mathrm{Ba}, \mathrm{Bi}$ and $\mathrm{Tl}$, moderately contaminated for $\mathrm{Zn}$ and $\mathrm{Mg}$, uncontaminated to moderately contaminated for $\mathrm{Sb}, \mathrm{Mn}$, $\mathrm{U}, \mathrm{P}, \mathrm{Na}, \mathrm{Ca}, \mathrm{Co}, \mathrm{K}$ and $\mathrm{As}$, and uncontaminated for $\mathrm{Sr}$, $\mathrm{Fe}, \mathrm{Al}, \mathrm{Hg}, \mathrm{V}, \mathrm{Cu}$ and $\mathrm{Ti}$.

According to the sampling stations, those with the highest geoaccumulation values are respectively 20, 26 and 24 , while stations with the lowest geoaccumulation values are 18, 13 and 6, respectively.

The Saricay basin is surrounded by extensive agricultural lands. $\mathrm{Cd}, \mathrm{Pb} \mathrm{Zn}, \mathrm{Ni}$ and As enrichment may be associated with fertilizers and pesticides used in farming (Cai et al., 2015; Köleli and Kantar, 2005). In addition, the mining map of Çanakkale province displays $\mathrm{Pb}-\mathrm{Zn}$ deposits in the basin that can be considered as sources of enrichment (https://www.mta.gov.tr/v3.0/sayfalar/hizmetler/madenharitalari/canakkale.pdf) and also shows the presence of barite, magnesite and gold deposits and silver works in the Saricay Basin. The raw materials of cement are also extracted from the region and $\mathrm{Na}, \mathrm{K}, \mathrm{Ca}, \mathrm{Fe}$ and $\mathrm{Al}$ are found in these raw materials (Kapkaç, 2007). Cement factories are also found in the basin. Tl accumulates in the atmosphere both from coal burning and cement production processes and is subsequently transported into the sediment (Karbowska, 2016). Cement factories in the region may also have contributed to $\mathrm{As}$ and $\mathrm{Cr}$ enrichment (Berg and Steinnes, 2005). Although bismuth is not harmful to the environment due to its low toxicity, it is used in industrial areas for pigments, pharmaceuticals and cosmetics (Yang and Sun, 2011) and may therefore cause various domestic wastes, depending on their usage. $\mathrm{Ni}$ can be released by burning fuels such as coal, diesel, and fuel oil (Cempel and Nikel, 2006). The enrichment levels for As and Sb were determined at the limit of "non-contamination-moderate contamination". Although these elements have predominantly natural sources, an atmospheric anthropogenic contribution is also possible: $\mathrm{Sb}$ from automotive fumes and As from coal combustion (Dousova et al., 2020). Similarly, Cr may be caused by vehicle fuels (Mishra and Bharagava, 2016).

The average mEri values of the heavy metals studied in Sarıçay River are listed in decreasing order as follows: $\mathrm{Cd}>\mathrm{Ni}>\mathrm{Pb}>\mathrm{Hg}>\mathrm{As}>\mathrm{Cr}>\mathrm{Co}>\mathrm{Zn}>\mathrm{Cu}>\mathrm{Mn}>\mathrm{Tl}>\mathrm{V}$. Considering the average mEri values: the potential ecological risk is very high for $\mathrm{Cd}$ and moderate for $\mathrm{Ni}$ and $\mathrm{Pb}$. Metals with low ecological risks are $\mathrm{Hg}, \mathrm{As}, \mathrm{Cr}$, $\mathrm{Co}, \mathrm{Zn}, \mathrm{Cu}, \mathrm{Mn}, \mathrm{Tl}$ and $\mathrm{V}$ (Fig. 4).

There is a very high ecological risk (PERI) at 25 of the 26 stations sampled in Saricay River (PER $\geq 600)$. On a station-to-station basis, those with the highest PERI values are 20, 21, and 19, respectively (Fig. 5). The stations with the lowest PERI values are 18, 2, and 5, respectively. The average PERI value of all 26 stations is 904.77. The maximum value is 1390.56 (station 20) and the minimum value is 559.85 (station 18).

\section{Statistical analyses}

Principal component analysis (PCA) was applied to the data set to identify possible sources of the metals. Seven components (PCs) with eigenvalues $>1$ were determined. The striking point in PCA is the coexistence of anthropogenic and lithogenic elements in its components, indicating that the elements come from their own sources and were redistributed by the same hydrogeochemical processes (Karthikeyan et al., 2018).

PC1 accounts for $34.59 \%$ of the total variance, consisting of $\mathrm{Cu}, \mathrm{Pb} \mathrm{Zn}, \mathrm{Ag}, \mathrm{Cd}, \mathrm{Bi}, \mathrm{Mg}$ and $\mathrm{Hg}$ (Table 2). This component mostly refers to basin-based elements that reach the river through flows. $\mathrm{Cu}, \mathrm{Pb}, \mathrm{Zn}$, $\mathrm{Ag}$ and $\mathrm{Mg}$ are the elements with deposits in the Sarıçay basin. $\mathrm{Hg}$ has a low value of $\mathrm{EF}$, coming from lithogenic sources. $\mathrm{Cd}$ arises from agricultural activities and $\mathrm{Bi}$ comes from waste water.

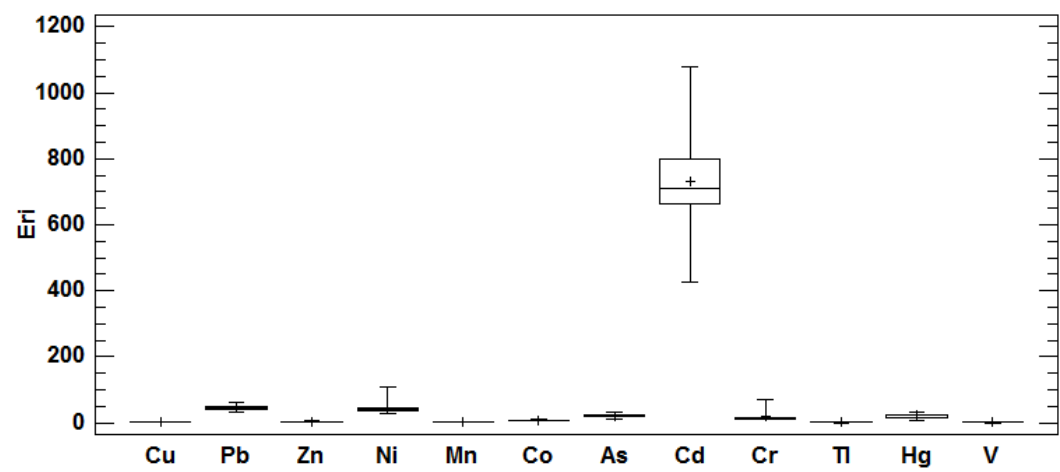

Fig.4. mEri values of trace element 


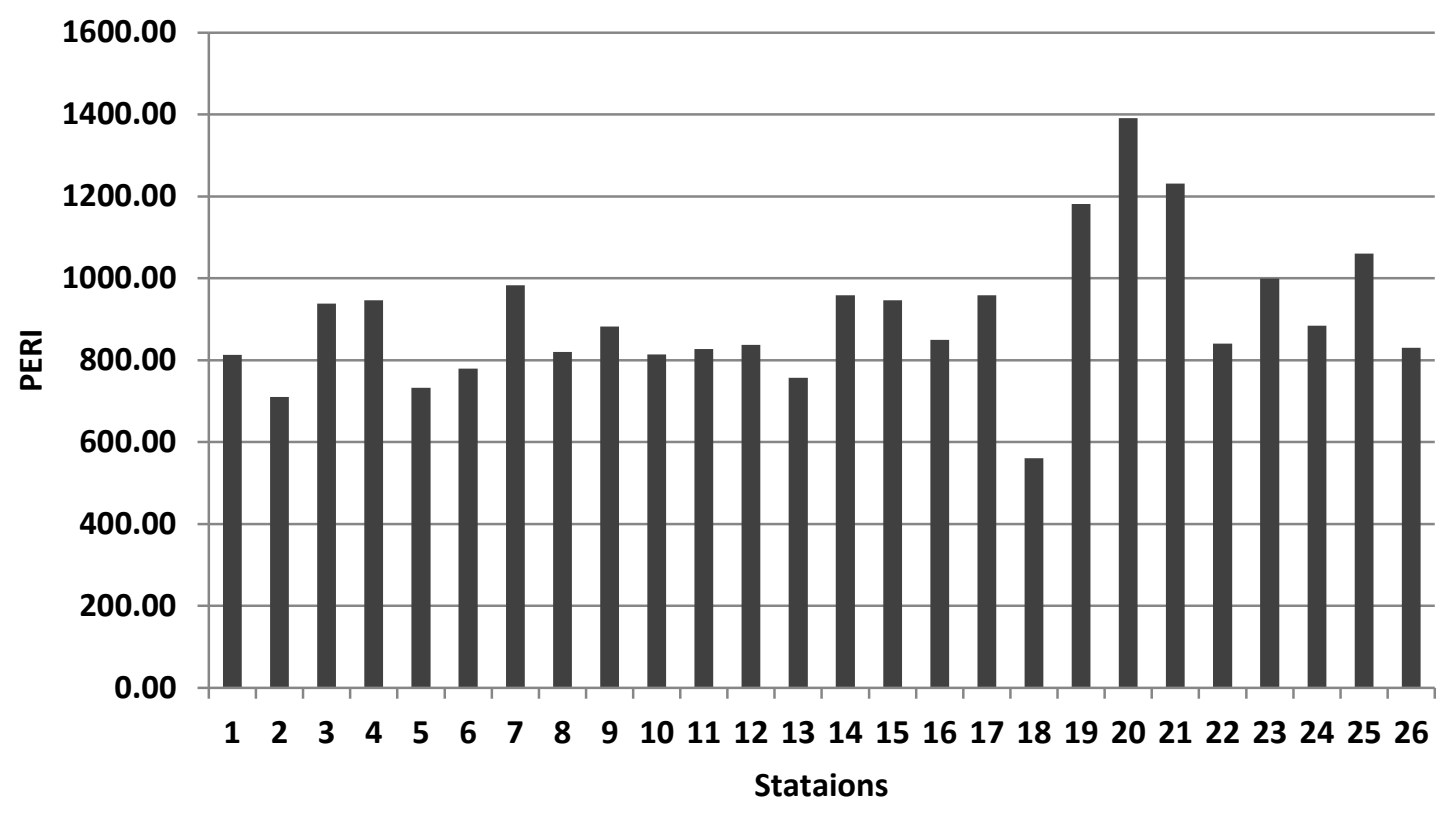

Fig.5. PERI values of stations.

The second component is responsible for $17.76 \%$ of the total variance and represents mainly atmospheric inputs. It consists of $\mathrm{Ni}, \mathrm{Au}, \mathrm{P}$ and $\mathrm{Cr}$ moving in the same direction and $\mathrm{Pb}$ and $\mathrm{Tl}$ moving in the opposite direction. $\mathrm{Pb}$ is an element whose weight is close to each other in the first two components, revealing that it has multiple sources. The source in the first component is considered lithogenic, and the second is atmospheric. Au within the component comes from mining activities. $\mathrm{Cr}$ and $\mathrm{Ni}$ may be due to the use of automotive fuel. It is thought that Tl may have been released from coal burning and mixed into the river.

The third component represents $13.79 \%$ of the variance and includes $\mathrm{Co}, \mathrm{Mn}, \mathrm{As}, \mathrm{Sr}$ and $\mathrm{Ba}$, revealing them to be of lithogenic origin due to weathering in the basin. Co and $\mathrm{Sr}$ arise entirely from natural sources. As and $\mathrm{Mn}$ are on the border of uncontaminated-moderate enrichment. Only $\mathrm{Ba}$ has a markedly high enrichment rate and the presence of barite deposits in the basin explains this enrichment. Co binds strongly to manganese and can be found in many minerals with As (Sigg and Behra, 2005). PC4 accounts for $6.87 \%$ of the total change and consists of $\mathrm{Sb}, \mathrm{Na}, \mathrm{K}$ and $\mathrm{Tl}$. This component represents industrial cement works; $\mathrm{Na}$ and $\mathrm{K}$ are extracted from the basin and used as cement raw materials. During the production of $\mathrm{Tl}$ cement, it oxidizes at high temperature and then concentrates as ash particles at low temperatures (Karbowska, 2016). PC5, PC6 and PC7 represent elements of completely natural origin transported into the sediment. It consists, in PC-5 of $\mathrm{U}$ and $\mathrm{Ti}$, in PC6 of Fe, V, and Ti, and in PC7 of Al, Ca, Sr and $\mathrm{Sb}$. $\mathrm{Sr}$ and $\mathrm{Sb}$ are also highly represented in other components as they have mixed sources.

\section{Conclusions}

Çanakkale city is under heavy pollution pressure from urbanization, industrialization and agricultural activities.
In this study, an element-based ecological risk assessment of Sarıçay River, which divides Çanakkale into two parts, was made. In the analysis of sediment samples taken along the river, anthropogenic enrichment was determined for $\mathrm{Cd}, \mathrm{Cr}, \mathrm{Ni}, \mathrm{Pb}, \mathrm{Au}, \mathrm{Ag}$ and $\mathrm{Ba}, \mathrm{Bi}$, $\mathrm{Tl}, \mathrm{Na}, \mathrm{Zn}, \mathrm{Mg}, \mathrm{K}, \mathrm{As}, \mathrm{Sb}$ and $\mathrm{Mn}$. The level of this enrichment varies from moderate to very high. According to the results of the risk analysis, a moderate risk for $\mathrm{Cd}$ was determined but it was very high for $\mathrm{Ni}$ and $\mathrm{Pb}$. Agricultural activities, atmospheric deposition and mineral deposits in the basin were identified as the main source of metal inflows. In Sarıçay River, which is one of the important water resources of the region, regular comprehensive basin-based assessments should be made by local government in order to control contaminant inputs and careful attention should be paid to the management of waste-generating resources, especially the use of fertilizers and pesticides on agricultural lands.

\section{Acknowledgements}

This study is supported by the Administration of the Scientific Research Projects of Çanakkale Onsekiz Mart University (Grant No. SYL-2018-2718). We would like to dedicate this study to the cherished memory of Prof. Dr. Telat Koç who died on January 21, 2021, making great efforts to solve anthropogenically-induced environmental problems in the city of Çanakkale.

\section{References}

Abonyi, A., Kiss. K.T., Hidas, A., Borics, G., Varbiro, G. and Acs, E. (2019). Cell size decrease and altered size structure of phytoplankton constrain ecosystem functioning in the middle Danube River over multiple decades. Ecosystems, doi.10.1007/S10021019-00467-6. 
Akcay, H., Oguz, A. and Karapire, C. (2003). Study of heavy metal pollution and speciation in Buyuk Menderes and Gediz river sediments. Water Research, 37: 813-822.

Akinci, G., Guven, D.E. and Keles Ugurlu, S. (2013). Assessing pollution in Izmir Bay from rivers in western Turkey: heavy metals. Environmental Science Processes and Impacts, 15:2252-2262.

Aksoy, T., Aydın, M., Tuncel, O. and Oner, O. (1997). Saricay'ın kurtarılması. Yerleşim ve Cevre Sorunları Sempozyumu: Canakkale Ili, Dokuz Eylul Universitesi, Cevre Muhendisligi Bolumu.

Algan O, Gökaşan E, Gazioğlu C, Yücel ZY, Alpar B, Güneysu C, Kırcı E, Demirel S, Sarı E, Ongan D (2002) A high-resolution seismic study in Sakarya Delta and submarine canyon, southern Black Sea shelf. Continental Shelf Research 22:1511-1527. doi.10.1016/S0278-4343(02)00012-2

Alkan, Y. 2020. User-focused alternative design model for Sarıçay channel and landscaping in terms of sports and health components: Çanakkale, Turkey, Environment, Development and Sustainability, doi.10.1007/s10668-020-00912-w.

Belis, C.A., Pisoni, E., Degrauwe, B., Peduzzi, E., Thunis, P., Monforti-Ferrario, F. and Guizzardi, D. (2019). Urban pollution in the Danube and Western Balkans regions: the impact of major PM 2.5 sources. Environmental International, 133. doi. 10. 1016/j.envint.2019.105158.

Benet, J. (2019). Anthropogenic stresses on the world's big rivers. Nature Geoscience, 12:7-21, DOI: 10.1038/s41561-018-0262-x.

Berg, T. and Steinnes, E. (2005). Atmospheric transport of Metals. In Metals Ions in Biological Systems (p. 348). Taylor \& Francis Group.

Bergamaschi, L., Rizzo, E., Valcuvia, M.G., Verza, G., Profumo, A., and Gallorini, M. (2002). Determination of trace elements and evaluation of the enrichment factors in Himalayan Lichens. Environmental Pollution, 120:137-144.

Cai, L., Xu, Z., Bao, P., He, M., Dou., Chen, L. et al. (2015). Multivariate and geostatistical analyses of the spatial distribution and source of arsenic and heavy metals in the agricultural soils in Shunde, Southeast China. Journal of Geochemical Exploration, 148, 189-195. doi,10.1016/j.gexplo.2014.09.010.

Cempel, M., and Nikel, G. (2006). Nickel: A Review of Its Sources and Environmental Toxicology. Polish Journal of Environmental Studies, 15(3), 375-382.

Dousova, B., Lhotka, M., Buzek, F., Cejkova, B., Jackova, I., Bednar, V., and Hajek, P. (2020). Environmental interaction of antimony and arsenic near busy traffic nodes. The Science of the Total Environment, 702, 134642. doi.10.1016/ j.scitotenv.2019.134642

Duruibe, J.O., Ogwuegbu, M.O.C. and Egwurugwu, J.N. (2007). Heavy metal pollution and human biotoxic effects. International Journal of Physical Sciences, 2(5):112-118.

El Bouraie, M.M., El Barbay, A.A., Yehia, M.M. and Motawea, E.A. (2010). Heavy concentrations in surface river water and bed sediments at Nile Delta in Egypt. Sou, 61(1):1-12.
Engin, M.S., Uyanik, A., Cay, S. and Kir, I. (2016). Evaluation of trace metals in sediment, water, and fish (Mugil cephalus) of Black Sea coast of Turkey. Human and Ecological Risk Assessment: An International Journal, 22(1):241-250.

Esen, E., Kucuksezgin, F. and Uluturhan, E. (2010). Assessment of trace metal pollution in surface sediments of Nemrut Bay, Aegean Sea. Environ Monit Assess, 160:257-266.

Esetlili, M., Bektas Balcik, F., Balik Sanli, F., Kalkan, K., Ustuner, M., Goksel, C., Gazioğlu, C., Kurucu, Y. (2018). Comparison of Object and Pixel-Based Classifications For Mapping Crops Using Rapideye Imagery: A Case Study Of Menemen Plain, Turkey. International Journal of Environment and Geoinformatics, 5(2), 231-243, doi. 10.30897 /ijegeo.442002.

Farkas, A., Erratico, C. and Vigano, L. (2007). Assessment of the environmental significance of heavy metal pollution in surface sediments of the River Po. Chemosphere, 68:761-768, DOI: 10.1016/j.chemosphere.2006.12.099.

Förstner, U. and Prosi, F. (1979). Heavy metal pollution in freshwater ecosystems. Proceedings of Course Held at the Joint Research Centre of the Commission of the European Communities, Ispra, Italy, 5-9 June 1978, doi, 10.1016/B978-0-08-023442-7.50011-6.

Gazioğlu, C. (2018). Biodiversity, Coastal Protection, Promotion and Applicability Investigation of the Ocean Health Index for Turkish Seas, International Journal of Environment and Geoinformatics, 5(3), 353-367. doi. 10.30897/ijegeo.484067.

Gazioğlu, C., Gökaşan, E., Algan, O. Yücel, Z. Y., Tok, B., Doğan, E., (2002). Morphologic features of the Marmara Sea from multi-beam data, Mar. Geol., 190(1-2): 397-420.

Gedik, K. and Boran, M. (2013). Assessment of metal accumulation and ecological risk around Rize Harbor, Turkey (Southeast Black Sea) Affected by Copper Ore Loading Operations by using different sediment indexes. Bull Environ Contam Toxicol, 90:176-181.

Gümgüm, B., Ünlü, E., Tez, Z. and Gülsün, Z. (1994). Heavy metal pollution in water, sediment and fish from the Tigris River in Turkey. Chemosphere, 29(1): 111-116.

Guo, W., Liu, X., Liu, Z. and Li, G. (2010). Pollution and Potential Ecological Risk Evaluation of Heavy Metals in the Sediments around Dongjiang Harbor, Tianjin. Procedia Environmental Sciences, 2:729-36, DOI: 10.1016/j.proenv. 2010.10.084.

Haciyakupoglu, S., Esen, A.N., Erenturk, S., Okka, M., Genceli, M., Mercimek, M., Genceli, E., Yusan, S., Gur Filiz, F., Olgen, K., Camtakan, Z., Kiziltas, S. and Tanbay, T. (2015). Determining distribution of heavy metal pollution in terms of ecological risk levels in soil of industrially intensive areas around Istanbul. Toxicological and Environmental Chemistry, 97(1):62-75.

Hawkes, J.S. (1997). Heavy metals. J Chem Edu, 74:1369-1374.

Hakanson, L. (1980). An ecological risk index for aquatic pollution control: a sedimentological 
approach. Water Research, 14:975-1001, doi. 10. 1016/0043-1354(80)90143-8.

Izah, S.C., Bassey, S.E. and Ohimain, E.I. (2017). Geoaccumulation index, enrichment factor and quantification of contamination of heavy metals in soil receiving cassava mill effluents in a rural community in the Niger Delta Region of Nigeria. Molecular Soil Biology, 8(2):7-20, doi, 10 $.5376 / \mathrm{msb} .2017 .08 .0002$.

Jarup, L. (2003). Hazards of heavy metal contamination. British Medical Bulletin, 68:167-182.

Kapkaç, F. (2007). Çimento Çeşitleri, Özellikleri, Hammaddeleri Ve Üretim Aşamaları, MTA Doğal Kaynaklar ve Ekonomi Bülteni, 223-232.

Karbowska, B. (2016). Presence of thallium in the environment: sources of contaminations, distribution and monitoring methods. Environmental Monitoring and Assessment, 188(11), 640. , doi.10.1007/s10661016-5647-y

Karthikeyan, P., Vennila, G., Venkatachalapathy, R., Subramani, T., Prakash, R., and Aswini, M. K. (2018). Assessment of heavy metals in the surface sediments of the Emerald Lake using of spatial distribution and multivariate techniques. Environmental Monitoring and Assessment, 190(11), 668. , doi.10.1007/s10661-018-7037-0

Kocum, E. and Dursun, O. (2007). Monitoring of phytoplankton biomass and nutrients in a polluted stream. Int. J. Environment and Pollution, 29(4):50517.

Köleli, N., and Kantar, Ç. (2005). Fosfat Kayas1, Fosforik Asit ve Fosforlu Gübrelerdeki Toksik Ağır Metal ( $\mathrm{Cd}, \mathrm{Pb}, \mathrm{Ni}$, As) Konsantrasyonu. Ekoloji, 14(55), 1-5.

Lasheen, M.R. and Ammar, N.S. (2009). Speciation of some heavy metals in River Nile sediments, Cairo, Egypt. Environmentalist, 29:8-16, doi. 10.1007 /s10669-008-9175-3.

Li, Y., Qu, X. Zhang, M., et al. (2018). Anthropogenic impact and ecological risk assessment of Thallium and Cobalt in Poyang Lake using the geochemical baseline. Water, 10, 1703; doi. 10.3390/w10111703.

Mendoza, H.H., Lugo, M.J.R., Guzman, E.T.R., Gutierrez, L.R.R. and Ketterer, M.E. (2018). Heavy metals monitoring in sediments from Lerna River in West-Central Mexico. American Journal of Analytical Chemistry, 9:77-87, doi. 10.4236/ ajac.2018.92007.

Mishra, S., and Bharagava, R. N. (2016). Toxic and genotoxic effects of hexavalent chromium in environment and its bioremediation strategies. Journal of Environmental Science and Health. Part C, Environmental Carcinogenesis \& Ecotoxicology Reviews, 34(1), 1-32. doi.10.1080/10590501. 2015.1096883

Muller, G. (1969). Index of geoaccumulation in sediments of the Rhine River. Geojournal, 108-118.

Nagajyoti, P.C., Lee, K.D. and Sreekanth, T.V.M. (2010). Heavy metals, occurrence and toxicity for plants: a review. Environ Chem Lett, 8:199-216, DOI: $10.1007 / \mathrm{s} 10311-010-0297-8$.
Ozseker, K., Eruz, C. and C1lı, S. (2013). Determination of copper pollution and associated ecological risk in coastal sediments of Southeastern Black Sea Region, Turkey. Bull Environ Contam Toxicol, 91:661-666.

Öztürk, B. and Erginal, A.E. (2001). Sarıçay havzasının jeomorfolojisi. Türk Coğrafya Dergisi, 36:49-86.

Pandey, P., Khillare, P.S. and Kumar, K. (2011). Assessment of organochlorine pesticide residues in the surface sediments of River Yamuna in Delhi, India. Journal of Environmental Protection, 2:511524, doi.10.4236/jep.2011.25059.

Paul, D. (2017). Research on heavy metal pollution of river Ganga: A review. Annals of Agrarian Science, 30:1-9, doi10.1016/j.aasci.2017.04.001.

Pekey, H., Karakaş, D., Ayberk, S., Tolun, L. and Bakoğlu, M. (2004). Ecological risk assessment using trace elements of Izmit Bay (Northeastern Marmara Sea) Turkey. Marine Bulletin, 48:946-953.

Polat, F., Akın, Ş., Yıldırım, A. and Dal, T. (2015). The effects of point pollutants-originated heavy metals (leads, copper, iron, and cadminium) on fish living Yeşilırmak River, Turkey. Toxicology and Industrial Health, 1-12.

Quinton, J.N. and Catt, J.A. (2007). Enrichment of heavy metals in sediment resulting from soil erosion on agricultural fields. Environ. Sci. Technol. 41(10): 3495-3500.

Rodriguez-Espinosa, P.F., Shuruti. VC, Jonathan, M.P. and Mattinez-Tavera, E. (2018). Metal concentrations and their potential ecological risks in fluvial sediments of Atoyac River basin, Central Mexico: Volcanic and anthropogenic influences. Ecotoxicological and Environmental Safety, 148:1020-1033, doi10.1016/j.ecoenv.2017.11.068.

Rusina, T.P., Smedes, F., Brboric, M. and Vrana, B. (2019). Investigating levels of organic contaminants in Danube River sediments in Serbia by multi-ratio equilibrium passive sampling. Science of the Total Environment, 696. doi10.1016/j.scitotenv. 2019.133935.

Salar, A., Gazioğlu, C. (2021). Tsunami Hazard Assessment and Potential Risk Mitigation Requirement for Sea of Marmara Coastline, International Journal of Environment and Geoinformatics, 8(3), 359-368, doi: 10.30897/ ijegeo.908180

Saikia, B.J., Parthasarathy, G., Borah, R.R. and Borthakur, R. (2016). Raman and FTIR Spectroscopic Evaluation of clay minerals and estimation of metal contaminations in natural deposition of surface sediments from Brahmaputra River. International Journal of Geosciences, 7:873883, doi.10.4236/ijg.2016.77064.

Satar, A.M.A., Ali, M.H. and Goher, M.E. (2017). Indices of water quality and metal pollution of Nile River, Egypt. Egyptian Journal of Aquatic Research, 43:21-29, doi 10.1016/j.ejar.2016.12.006.

Sigg, L. and Behra, R. (2005). Speciation and Bioavailability of Trace Metals in Freshwater Environments. In Metal ions in biological systems (Vol. 44, pp. 47-73). Taylor \& Francis Group.

Srivastava, V., Sarkar, A., Singh, S., Singh, P., de Araujo, A.S.F. and Singh, R.P. (2017). 
Agroecological responses of heavy metal pollution with special emphasis on soil health and plant performance. Front. Environ. Sci. 5:64. doi: 10.3389/fenvs.2017.00064.

Sur H. İ., Okuş E., Güven K.C., Yüksek A., Altık H., Kıratlı N., Ünlü S., Taş S., Aslan-Yılmaz A., Yılmaz N., Övez S., Müftüoğlu A. E., Karhan Ü., Öz İ. Demirel N. (2004), Water Quality Monitoring, Annual Report. Submitted to: İstanbul Water and Sewerage Administration (ISKI). Istanbul University, Institute of Marine Sciences and Management, İstanbul.

Surresh, G., Ramasamy, V., Meenakshisundaram, V., Venkatachalapathy, R. and Ponnusamy, V. (2011). Influence of mineralogical and heavy metal composition on natural radionuclide concentrations in the river sediments. Applied Radiation and Isotopes, 69(10):1466-1474.

Sutherland, R.A. (2000). Bed sediments-associated trace metals in an urban stream in Oahu, Hawaii. Environmental Geology, 39:611-627, DOI: 10.1007/s002540050473.

Tchounwou, P.B., Patlolla, A.K. and Centeno, J.A. (2003). Carcinogenic and systemic health effects associated with arsenic exposure-a critical review. Toxicol Pathol, 31:575-588.

Tchounwou, P.B., Yedjou, C.G., Patlolla, A.K. and Sutton, D.J. (2012). Molecular, Clinical and Environmental Toxicology, 101: 133-164, DOI: 10.1007/2F978-3-7643-8340-4_6.

Telxeira, R.A., Fernandes, A.R., Ferreira, J.R., Vasconcelos, S.S. and De Souza Braz A.M. (2018). Contamination and soil biological properties in the Serra Pelada Mine-Amazonia, Brazil. Revista Brasileira de Ciencia do Solo, 42:1-15, doi.10. 1590/18069657rbcs20160354.

Tiryaki, M., Karaca, Ö. (2018). Flood susceptibility mapping using GIS and multicriteria decision analysis: Saricay-Çanakkale (Turkey), Arabian Journal of Geosciences, 11: 364,doi.10.1007/s12517018-3675-3.

Tomlinson, D.L., Wilson. J.G., Harris, C.R. and Jeffney, D.W. (1980). Problem in the assessment of heavy metal levels in estuaries and the formation of a pollution index. Helgol Wiss Meeresunters, 33:566572.

Toth, G., Hermann, T., Da Silva, M.R., and Montaneralla, L. (2016). Heavy metals in agricultural soils of the European Union with implications for food safety. Environ. Pollut. 88:299-309. Doi: 10.1016/j.envint.2015.12.017.

Ünlü, S. and Alpar, B. (2015). An assessment of metal contamination in the shelf sediments at the southern exit of Bosphorus Strait, Turkey. Toxicological and nd Environmental Chemistry, 97:6, 723-740.

Ustaoğlu, F. and Tepe, Y. (2019). Water quality and sediments concentration assessment of Pazarsuyu Stream, Turkey using multivariate statistical methods and pollution indicators. International Soil and Water Conservation Research, 7:47-56.

Varol, M. (2011). Assessment of heavy metal contamination in sediments of the Tigris River (Turkey) using pollution indices and multivariate statistical techniques. Journal of Hazardous Materials, 195:355-364.

Wei, L., Wang, K., Noguera, D.R., Jiang, J., Oyserman, B., Zhao, N., Zhao, Q. and Cui, F. (2016). Transformation and speciation of typical heavy metals in soil aquifer treatment system during long time recharging with secondary effluent: Depth distribution and combination. Chemosphere, 165:100-109, doi, 10.1016/j.chemosphere.2016. 09.027.

Xu, X., Nie, S., Ding, H. and Fan Hou, F. (2018). Environmental pollution and kidney diseases. Nature Reviews Nephrology, 14:313-324, doi.10.1038/ nmeph.2018.11

Yang, N. and Sun, H. (2011). Bismuth: Environmental Pollution and Health Effects. Encyclopedia of Environmental Health, 414-420. , doi.10.1016/B9780-444-52272-6.00374-3

Yanqun, Z., Yuan, L., Jianjun, C., Haiyan, C., Li, Q. and Schvartz. C. (2005). Hyperaccumulation of $\mathrm{Pb}, \mathrm{Zn}$ and $\mathrm{Cd}$ in herboceous grown on lead-zinc mining area in Yunnan, China. Environ. Int. 3, 755-762. Doi: 10.1016/j.envint.2005.02.004.

Zhang, H., Jiang, Y., Ding, M. and Xie, Z. (2017). Level, source identification, and risk analysis of heavy metal in surface sediments from river-lake ecosystems in the Poyang Lake, China. Environmental Science and Pollution Research, 24(27). 21902-21916. Doi: 10.1007/s11356-0179855-y.

Zhou, Q., Yang, N., Li, Y., Ren, B., Ding, X., Bian, H. and Yao, X. (2020). Total concentrations and sources of heavy metal in global river and lake water bodies from 1972 to 2017. Global Ecology and Conservation, 27. Doi: 10.1016/j.gecco.2020.e00925. 